\title{
Analysis of Method Used to Predict Financial Distress Potential in Pulp and Paper Companies of Indonesia
}

\author{
Fadrul $^{1}$, Ridawati $^{2}$
}

\begin{abstract}
:
This study aims to predict financial distress in pulp and paper companies in Indonesia. The data used are the financial statements of each pul and paper company listed on the Indonesia Stock Exchange in 2012-2017.

Data analysis techniques used descriptive analysis with three methods of financial distress prediction, namely the Altman Z-Score, Springate, and Zmijewski methods. The results showed that the Zmijewski method is a prediction method with the highest accuracy rate of $100 \%$, with an error type of $0 \%$. The Altman Z-Score method has an accuracy rate of $28.6 \%$, with an error type of $71.4 \%$.

While the Springate method has an accuracy rate of $14.3 \%$, with an error type of $85.7 \%$. Therefore an accurate prediction method to predict the potential for financial distress is the Zmijewski method.
\end{abstract}

Keywords: Financial Distress, Altman Z-Score, Springate, Zmijewski

\footnotetext{
${ }^{1}$ School of Business Pelita Indonesia, Dept of Accounting, fadrulwf@gmail.com

${ }^{2}$ School of Business Pelita Indonesia, Dept of Accounting, rydaawatiipku@gmail.com
} 


\section{Introduction}

Indonesia is still an investment destination for foreign industry players who want to invest their capital for business expansion. In addition to being supported by a large market potential, Indonesia has several industrial structures that can work well. One of them is the pulp and paper industry, which is an industry that processes wood as a basic material for producing pulp, paper, boards, and other products. This is because Indonesia has vast forest land, some of the vast forest is economically exploited. The economic use of forests in Indonesia comes from one of its products in the form of wood, which produces a derivative product, one of which is pulp and paper.

Paper for office operations is an important component. Because until now almost all offices still use paper for printing devices, besides that paper is in the national interest to advance education and cultural development. In addition to being a strategic sector, pulp and paper companies face low producer margins lately where producer margins are low, which is the condition that occurs when the cost of goods sold increases but the selling price of a product remains.

The phenomenon is where the price of paper raw materials continues to soar up then the demand for paper products every year also increases but the selling price tends to decrease. The fall in prices can affect the income or profits generated by the company. High demand but not followed by price increases will affect how raw materials are purchased, too many raw materials while losses can also cause losses in fixed assets so that it can lead to financial distress, even will trigger bankruptcy because the amount of net income has decreased. Declining income will not cover costs that will be paid so that the potential for bankruptcy is even greater. When viewed from the price of raw materials continue to rise, so that it is necessary to do a performance appraisal to avoid companies from bankruptcy by using some method analysis.

Bankruptcy can be caused by internal or external factors. The cause of bankruptcy due to internal factors include poor management so that a company cannot obtain profits to be able to run its business. While the causes of bankruptcy due to external factors, among others, come from outside the company and are beyond the reach or control of the company's leadership, among others, there is intense competition, then such as the monetary crisis, the country's political conditions that are not conducive and others. Internal and external factors can be a reference to assess the survival of a company.

To prevent bankruptcy, the company must know the level of bankruptcy that it has from year to year and so the company can maintain or improve the company's performance in the future. To find out a level of bankruptcy, an analysis of bankruptcy is needed. Bankruptcy is an essential problem that companies must watch out for. Because if the company has been exposed to financial distress, then 
the company is really experiencing business failure. For this reason, companies must conduct various analyzes as early as possible, especially those involving bankruptcy.

\section{Theoretical Background}

\subsection{Bankruptcy}

According to Fitriani (2011), bankruptcy is the failure of a company in carrying out its operations to generate profits. Furthermore, Onakoya \& Olotu (2017) stated that bankruptcy is when a company cannot generate enough revenue to cover its costs, in this case, such a company, is said to manifest negative economic value. Meanwhile, Venkataramana et al. (2012) stated bankruptcy is a situation where liabilities exceed assets in a company, generally, it occurs due to lack of capital, not maintaining sufficient cash, sources are not utilized properly, management of activities is inefficient, sales decline, and the market situation deteriorates.

Bankruptcy of a company is usually characterized by ongoing financial difficulties to finance operating activities, difficulty in attracting loans from creditors and refinancing. Financial distress according to Sundjaja et al. (2010), is a situation where operating cash flow is insufficient to finance existing obligations such as paying business debt or paying interest and this forces the company to take corrective action.

Setiadi (2011) states bankruptcy can be classified into two parts, namely: (1) Economic Failure (financial distressed) is a situation where a company has lost money to cover the costs of the company itself. This means that the company's profit rate is not more than its capital cost and the present value of its cash flow does not exceed or is lower than its liabilities. (2) Financial Failure (financial distressed) is defined as an insolvency that distinguishes on the basis of cash flow and the basis of shares. Insolvency itself is a condition where the liability of a company exceeds the amount of its assets. Insolvency on the basis of cash flows consists of two forms, namely: (a) Technical insolvency (technical insolvency) is a condition in which a company cannot fulfill its obligations when due even though the total assets have exceeded the total amount of liabilities. (b) Insolvency in the sense of bankruptcy that is the present value of the expected cash flows that is smaller than the liability.

Setiadi (2011) identified the factors causing a bankruptcy can be divided into two, namely: (1) Internal factors, where management does not run efficiently and cannot fulfill its obligations, there is a waste and an imbalance of the amount of capital owned by the total debts owed exists and with the amount of debt that is there will result in a large amount of interest thereby reducing company profits. Fraud from management can also result in bankruptcy. (2) External factors, such as changes in customer desires that are not anticipated by the company, suppliers who cannot meet raw material requirements, excessive amounts of receivables, bad relationships with 
debtors, tight business competition and global economic conditions that must also be considered.

\subsection{Bankruptcy prediction methods}

Altman (1968), Beaver (1966) and Ohlson (1980) were the first generation to introduce a method for analyzing the bankruptcy of a company. As time goes by the method of predicting bankruptcy continues to grow, this is due to the prediction of bankruptcy risk increasingly important for corporate governance Horvathova \& Mokrisova (2018). Until now many models have been developed by experts to predict the bankruptcy of companies, with their strengths and weaknesses, and it is not easy to choose these methods to be used empirically (Aziz \& Dar 2006). Today Agarwal \& Taffler (2008), Das et al. (2009) and Bauer and Agarwal (2014) have proven the reliability of prediction models based on accounting, markets, and hazards. From the accounting side, known factors that can affect financial distress (financial distress) include profitability ratios (Chancharat, 2008; Nur Hafizah, 2015; Idris, 2008; Liloshna et al, 2017) and liquidity ratios (Khunthong, 1997; Nur Hafizah, 2015).

Bankruptcy that occurred in banks began with the deteriorating condition of the Indonesian economy in early 1997. High-interest rates, rushes, debt swell, low customer deposits, and high bad loans hit almost all banks in Indonesia. However, this is not the main factor causing bankruptcy in banking institutions, this is proven by the existence of several banks until now, according to Munawir (2010) some factors cause bankruptcy in a company are general factors, external factors and internal factors.

General Factors, namely: (1) Economic Sector, namely the effect of the economic sector on bankruptcy stemming from the symptoms of inflation and deviation in the price of goods and services, government fiscal policy, interest rates, and currency devaluation or revaluation. (2) Social Sector, i.e. the influence of the social sector comes from changes in people's lifestyles that affect the demand for products and services or that relate to employees. (3) Technology Sector, namely the influence of the technology sector derived from the use of technology requires costs borne by the company, especially for maintenance and implementation. (4) Government Sector, namely the influence of the government sector originating from government policies on the removal of subsidies to companies and industries, the imposition of export and import tariffs on changed goods, the policy of new laws for banks or labor and others.

External Factors, namely: (1) The customer or customer sector, to avoid losing bank customers, must identify the characteristics of consumers or customers and also create opportunities to find new customers. (2) The creditor sector is where the power lies in lending and specifying a period of repayment of accounts payable 
which depends on the creditor's confidence in the liquidity of a bank. (3) Other competitor/bank factors, which are things that must be considered because they involve differences in the provision of services to customers.

Internal factors, namely: (1) Too much credit is given to customers so that it will cause arrears in payment until finally unable to pay. (2) Inefficient management caused by lack of ability, experience, skills, adaptive attitude and initiative from management. (3) Abuse of authority and fraud where employees are often committed, even top managers are very detrimental especially those related to corporate finance.

\subsection{Altman Z-score method}

According to Burhanuddin and Rizky (2015), after being pioneered by Beaver in 1966, Edward Altman also researched financial distress. Altman did what Beaver (1966) suggested at the end of his writing, which was to conduct a multivariate analysis. The method proposed by Altman later became the most popular method for predicting financial distress. The method is known as the Z-Score. Altman uses the step-wise multivariate discriminant analysis (MDA) method in his research.

Like logistic regression, this statistical technique is also commonly used to create methods where the dependent variable is qualitative. The output of the MDA technique is a linear equation that can distinguish between two states of the dependent variable. The sample used by Altman in his research totaled 66 companies for 20 years (1946-1965). The sample is divided into two groups, namely 33 companies that are considered bankrupt and 33 other companies that are not bankrupt. Companies that are considered bankrupt are companies that filed for bankruptcy according to the National Bankruptcy Act Chapter X. The company used by Altman only came from the manufacturing industry. The reason behind this is the same as the reason Beaver (1966) is that the available data only comes from Moody's Industrial Manual which only contains data on manufacturing companies. Seen from the number of samples, Altman also uses matched-paid techniques in the selection of samples. Like Beaver (1966), matched-pair used by Altman also uses 2 criteria, namely industry and company size (total assets). But in contrast to Beaver, who compared one by one the total assets of the two sample groups, Altman only saw the average difference between the two sample groups.

Altman's research initially collected 22 company ratios that might be useful for predicting financial distress. From these 22 ratios, tests are conducted to choose which ratios will be used in making the model. Testing is done by looking at the statistical significance of the ratio, correlation between ratios, the ability to predict ratios, and judgment of the researchers themselves. The ratio test results choose five ratios that are considered the best to be used as variables in the method. 
The Altman Z-Score is determined using the following formula:

$$
Z=1,2 X 1+1,4 X 2+3,3 X 3+0,6 X 4+1,0 \times 5
$$

$\mathrm{X} 1$ = working capital / total assets

$\mathrm{X} 2$ = retained earnings / total assets

$\mathrm{X} 3$ = earnings before interest and taxes / total assets

$\mathrm{X} 4$ = market value equity / book value of total debt

$\mathrm{X} 5$ = sales / total assets

The criteria used to predict bankruptcy of companies with this method are, companies that have a $\mathrm{Z}$ score $>2.99$ are classified as healthy companies, while companies that have a $\mathrm{Z}$ score of $<1.81$ are classified as potential companies going bankrupt. Furthermore, scores between 1.81 - 2.99 are classified as companies in the gray area.

\subsection{Springate Method}

According to Burhanuddin and Rizky (2015), Springate made a financial distress prediction model in 1978. In its manufacture, Springate used the same method as Altman, Multiple Discriminant Analysis (MDA). Like Beaver (1966) and Altman (1968), initially, Springate (1978) collected popular financial ratios that could be used to predict financial distress. The number of initial ratios was 19 ratios, after going through the same test conducted by Altman (1968), Springate chose 4 ratios that were believed to be able to distinguish between companies that experienced distress and those that did not. The samples used by Springate are 40 companies located in Canada.

The Springate Method formulates:

$$
S=1,03 X 1+3,07 X 2+0,66 X 3+0,4 X 4
$$

$\mathrm{X} 1$ = working capital / total assets

$\mathrm{X} 2=$ net profit before interest and taxes / total assets

$\mathrm{X} 3$ = net profit before taxes / current liability

$\mathrm{X} 4$ = sales $/$ total assets

Springate (1978) stated that the cut-off value that applies to this model is $0.862 . \mathrm{S}$ value smaller than 0.862 indicates that the company is predicted to go bankrupt. This 
method has an accuracy of $92.5 \%$ in tests conducted by Springate.

\subsection{Zmijewski Method}

According to Sari (2014), the prediction method produced by Zmijewski in 1983 was a 20-year research that had been repeated. Zmijewski (1983) uses liquidity ratio analysis, leverage and measures the performance of a company. Zmijewski made predictions with a sample of 75 bankrupt companies and 73 healthy companies during 1972 to 1978 , the F-Test indicator of the group ratio of the rate of return, liquidity, return on return, fixed payment coverage, trends, firm size, and stock return volatility, showed significant differences between healthy and unhealthy company.

With the assessment criteria, the greater the value of $X$, the greater the probability/probability of the company going bankrupt.

$$
X=-4,3-4,5 X 1+5,7 \times 2-0,004 X 3
$$

$\mathrm{X} 1$ = earning after tax / total assets

$\mathrm{X} 2=$ total debt $/$ total assets

$\mathrm{X} 3$ = current assets / current liabilities

The cutoff value that applies in this model is 0 . This means that companies with a value of $X$ greater than or equal to 0 are predicted to experience bankruptcy in the future. Conversely, companies that have a value of less than 0 are predicted not to experience bankruptcy. Zmijewski has measured the accuracy of his model with accuracy values.

\section{Methodology}

\subsection{Sample and data}

The population in this study are all Pulp \& Paper companies listed on the Indonesia Stock Exchange in 2012-2017. The sampling method used was purposive sampling, so the number of samples obtained in this study were 9 companies. 


\subsection{Operational of Variables}

\section{Altman Z-score method}

The financial ratios uses in the Altman Z-score model are:

$\mathrm{XI}=$ Working capital $/$ total assets

$\mathrm{X} 2$ = Retained earnings / total assets

$\mathrm{X} 3$ = Earrning before interest and tax / total assets

$\mathrm{X} 4$ = Market value of equity / book value of total debt

$\mathrm{X} 5=$ Sales $/$ total assets

The variable $\mathrm{Z}$ is the total value of the five financial ratios after multiplied by the coefficient of each ratio. This value indicates the possibility of bankruptcy and bankruptcy in the company after compared with the cut off value.

\section{Springate Method}

The financial ratios uses in the Springate model are:

$\mathrm{X} 1$ = working capital / total assets.

$\mathrm{X} 2=$ net profit before interest and taxes / total assets.

$\mathrm{X} 3$ = net profit before taxes / current liability.

$\mathrm{X} 4=$ sales $/$ total assets.

Springate (1978) in the discovery put forward the cut off value that applies to this model is 0.862 . $\mathrm{S}$ value smaller than 0.862 indicates that the company is predicted to go bankrupt. This model has an accuracy of $92.5 \%$ in tests conducted by Springate.

\section{Zmijewski Method}

The financial ratios uses in the Zmijewski model are:

$\mathrm{X} 1=$ Earning after tax $/$ Total Assets

$\mathrm{X} 2=$ Total Debt $/$ Total Assset

X3 = Current Asset $/$ Current Liabilities

The cut off value that applies in this model is 0 . This means that companies with a value of $\mathrm{X}$ greater than or equal to 0 are predicted to experience bankruptcy in the future. Conversely, companies that have a value of less than 0 are predicted not to experience bankruptcy. Zmijewski has measured the accuracy of his model with an accuracy value of $94.9 \%$. 


\subsection{Data analysis technique}

According to Prihadi (2010), each method always has the possibility of wrong prediction and level differences accuracy. It is difficult to expect whether there are predictors with $100 \%$ accuracy. Prediction tools are said to be true if the predicted and the actual are the same, while errors occur if the predicted and the actual are not the same. Errors arising from prediction tools consist of: (1) Type I errors, errors where the predictor states that it is not bankrupt is actually bankrupt. (2) Type II error, an error in which the prediction tool states that it is bankrupt is actually not bankrupt.

$$
\text { Accuracy Level }=\frac{\text { Number of correct predictions }}{\text { Number of samples }} \times 100 \% \text { Number of samples }
$$

In addition to the accuracy of this study also analyzed the percentage of types of errors. Type I errors are errors that occur if the sample prediction method does not go bankrupt when in fact it is bankrupt. Type II errors are errors that occur if the sample prediction method is bankrupt when in fact it is not bankrupt. The error type level can be calculated as follows:

$$
\begin{gathered}
\text { Type } I=\frac{\text { Number of type I errors }}{\text { Number of samples }} \times 100 \% \text { Number of Samples } \\
\text { Type II }=\frac{\text { Number of type II errors }}{\text { Number of samples }} \times 100 \% \text { Number of Samples }
\end{gathered}
$$

The level of accuracy and type of error is then used to deduce which method is most suitable to be applied. The prediction method has the highest accuracy in predicting bankruptcy or not a manufacturing company on the IDX.

\section{Empirical Findings}

The following is the level of accuracy and error in evaluating financial distress from the three models used:

Table 1. Level of Accuracy and Error in Evaluating Financial Distress

\begin{tabular}{ccc}
\hline Method & Level of Accuracy & Level of Error \\
\hline Altman Z-Score Method & $28,6 \%$ & $71,4 \%$ \\
Springate Method & $14,3 \%$ & $85,7 \%$ \\
Zmijewski Method & $100 \%$ & $0 \%$ \\
\hline
\end{tabular}

Source: Processed Data (2019)

\subsection{Altman Z-Score Method}

Based on the calculation of predictions using the Almant Z-Score method, the result presents that of 7 companies that were assessed bankruptcy predictions, 2 companies 
did not experience financial distress and 5 companies experienced financial distress. The resulting accuracy level of $28.6 \%$ and an error rate of $71.4 \%$.

The method proposed by Altman is the most popular method for predicting financial distress today. The method is known as the Z-Score. In the Almant Z-Score method as a tool in predicting bankruptcy, the company is more valued in terms of capital management-owned to increase the amount of company assets, measuring the company's ability to utilize the amount of assets owned to produce optimal profits. The Almant Z-Score method also evaluates the company's performance in terms of the number of assets managed to obtain gross profit, namely profit before interest and taxes. With the Almant Z-Score method also in assessing bankruptcy by conducting an assessment of the company's market value and sales generated within a period. The results of this study are also in line with the results of the study of Peter and Yoseph (2011) where the Almant Z-Score method has the ability to predict bankruptcy of a company.

\subsection{Springate Method}

Based on the prediction calculation using the Springate method, the result presents that of 7 companies that were assessed bankruptcy, 1 company did not experience financial distress and 6 companies experienced financial distress. With the resulting accuracy level of $14.3 \%$ and an error rate of $85.7 \%$.

The Springate model uses more than one financial ratio related to company bankruptcy to form a good model. To determine which ratios can detect the possibility of bankruptcy. This method assesses bankruptcy of a company based on the company's ability to manage working capital to get the amount of assets owned by the company, in addition to this method also assesses how the company gets net profit from total assets owned by the company. The Springate method also assesses the company's ability to manage net income to cover the current debt owed by the company and assesses bankruptcy by looking at the sales generated by comparing the total assets owned by the company. The results of this study are also in line with the results of the research of Peter and Yoseph (2011) where the Springate method has the ability to predict a company's bankruptcy.

\subsection{Zmijewski Method}

Based on the prediction calculation using the Zmijewski method, the result presents that of 7 companies assessed as bankruptcy predictions, the entire sample did not experience financial distress, with the resulting accuracy level of $100 \%$ and an error rate of $0 \%$. This method adds financial ratios as a means of detecting corporate financial failures. In the Zmijewski method, the financial ratios used are profitability ratios aimed at assessing the company's ability to generate company profits, liquidity ratios to assess the company's ability to cover the amount of debt held and the 
company's ability to utilize current assets to cover the current debt owed by the company.

Zmijewski's model uses financial ratios that measure the company's performance, financial performance and liquidity to develop its model. Then based on the results of the research in this study results that the Zmijewski method as a method that has better accuracy than the al-zant score and springate methods in assessing bankruptcy predictions in the Pulp Company \& Paper in the period 2012-2017.

\section{Conclusions}

The purpose of this study is to predict financial distress in pulp and paper companies in Indonesia during the 2012-2017 period. In predicting financial distress, three methods are used, namely the Altman Z-Score, Springate and Zmijewski methods.

The results showed that the Zmijewski method is a prediction method with the highest accuracy rate of $100 \%$, with an error level of $0 \%$. The Altman Z-Score method has an accuracy rate of $28.6 \%$, with an error level of $71.4 \%$. While the Springate method has an accuracy rate of $14.3 \%$, with an error level of $85.7 \%$. Therefore an accurate prediction method to predict the potential for financial distress is the Zmijewski method.

\section{References:}

Agarwal, Vineet, and Richard Taffler. (2008). Comparing the performance of market-based and accounting-based bankruptcy prediction models. Journal of Banking \& Finance 32: 1541-51.

Altman. E.I. (1968). Financial Ratio Descriminant Analisis and The Prediction of Corporate Bankruptcuy. Jurnal of Finance. Vol. XXIII, No.4 Page 589609.

Aziz, Adnan A., and Humayon A. Dar. (2006). Predicting corporate bankruptcy: where we stand? Corporate Governance 6: 18-33.

Burhanuddin \& A. Rizky. (2015). Analisis Penggunaan Metode Altman Z-Scoredan Metode Springate untuk mengetahui Potensi Terjadinya Financial Distress pada Perusahaan Manufaktur Sektor Industri Dasar Dan Kimia Sub Sektor Semen Periode 2009-2013.

Bauer, Julian, and Vineet Agarwal. (2014). Are hazard models superior to traditional bankruptcy prediction approaches? A comprehensive test. Journal of Banking \& Finance 40: 432-42.

Beaver. W. (1966). Financial Ratio As Predictors Of Failur. Journal Of Accounting Research. Page 71-105. 
Chancharat, N. (2008). An empirical analysis of financially distressed Australian companies: the application of survival analysis.

Christianti, A. (2013). Akurasi Prediksi Financial Distress: Perbandingan Model Altman Z-Score dan Ohlson. Jurnal Ekonomi \& Bisnis Vol 7, No. 2, Juli 2013 Hal. 77-89.

Das, Sanjiv R., Paul Hanouna, and Atulya Sarin. (2009). Accounting-Based versus Market-Based cross-sectional models for CDS spreads. Journal of Banking \& Finance 33: 719-30.

Fitriani, W. (2011). Penggunaan Metode Altman Z-Score Dalam Memprediksi Kebangkrutan Perusahaan. Fakultas Ekonomi, Universitas Parahyangan.

Firdausia, Y.K. (2017). Analisis Z-Score untuk memprediksi Financial Distress pada Perusahaan Tekstil dan Garment. Dalam media riset ekonomi. Vol 22 No. 1 Juli. Hal 19-22.

Horvathova, Jarmila \& M. Mokrisova. (2018). Risk of Bankruptcy, Its Determinants and Models. Risks 2018, 6, 117.

Idris, N. F. (2008). Financial ratios as the predictor of corporate distress in Malaysia. University of Malaya.

Khunthong, J. (1997). Red flags on financial failure: the case of Thai corporations.

Liloshna, L., Sharmila, L., Felix, G., Nair, M., Nair, B., \& Tushaline, S. (2017). A Study on the Predictions of Financial Distress in Malaysia. UTAR.

Munawir. (2010). Analisis Laporan Keuangan. Edisi Ketiga Belas. Yogyakarta. Libery.

Nur Hafizah, R. (2015). Determinants of financial distress among manufacturing companies in Malaysia. Universiti Utara Malaysia.

Ohlson, J.A. (1980). Financial Ratios and the Probabilistic Prediction of Bankruptcy. Journal of Accounting Research, 18(No.1).

Onakoya, A.B \& A. E. Olotu. (2017). Bankruptcy and Insolvency: An Exploration of Relevant Theories. International Journal of Economics and Financial Issues, 2017, 7(3): 706-712.

Peter \& Yosep. (2011). Analisis Kebangkrutan dengan metode Altman Z-Score, Springate dan Zmijewski pada PT. Indofood Sukses Makmur Tbk Periode 2005-2009. Akurat Jurnal Ilmiah Akuntansi Nomor 04 Tahun ke-2.

Prihadi, T. (2010). Deteksi Cepat Kondisi Keuangan, Analisis Rasio Keuangan. Jakarta: Ppm Manajemen.

Setiadi, A. (2011). Analisis Financial Distress Terhadap Prediksi Kebangkrutan Dengan Menggunakan Altman's Z-Score Studi Kasus pada PT. Bakrie \& Brothers Tbk. Fakultas Ekonomi, Universitas Komputer Indonesia. 
Sofiana. (2015). Perbandingan Potensi Kebangkrutan Pada Perusahaan Sub Sektor Pertambangan Batu Bara, Logam dan Mineral yang terdaftar di Bursa Efek Indonesia (BEI) sebelum dan setelah penerapan Minerba No.4 Tahun 2009 ditahun 2014 (Altman Z-Score), Skripsi S1 Program Studi Akuntansi Sekolah Tinggi Pelita Indonesia Pekanbaru.

Springate, Gordon L.V. (1978). Predicting The Possibility of Failure in a Canadian Firm. Unpublised Masters Thesis. Simon Fraser Univrsity. January 1978.

Sari, E.W. (2014). Penggunaan Model Zmijeski, Springate, Altman Z-Score, dan Grover dalam Memprediksi Kepailitan pada Perusahaan Transportasi yang Terdaftar di Bursa Efek Indonesia. Universitas Dian Nuswantoro.

Sari, E.A.R. (2014). Pengaruh Partisipasi Masyarakat dan Transparasi Kebijakan Publik serta Pengetahuan Dewan terhadap Anggaran dalam Penyusunan APBD. Program Studi Akuntansi Fakultas Ekonomi dan Bisnis. Universitas Muhammadiyah Surakarta.

Venkataramana, N., Md. Azash, and K. Ramakrishnaiah. (2012). Financial Performance and Predicting the Risk of Bankruptcy: A Case of Selected Cement Companies in India. International Journal of Public Administration and Management Research 1: 40-56.

Zmijewski, M.E. (1983). Methodological Issue Related to The Estimation of Financial Distress Prediction Models. Journal of Accounting Research 22, 59-82. 